\title{
Knowledge, attitude and seropositivity of hepatitis B virus among blood donors in the Bamenda Regional Hospital Blood Bank, Cameroon
}

Moses Samje ( $\sim$ msamje@yahoo.com )

University of Bamenda https://orcid.org/0000-0001-5323-6023

\section{Sylvain Sop}

University of Bamenda

Claude Tagny Tayou

Universite de Yaounde I

Dora Mbanya

Universite de Yaounde I

Research article

Keywords: hepatitis B virus, seropositive, knowledge, attitude, blood donors

Posted Date: July 22nd, 2020

DOI: https://doi.org/10.21203/rs.3.rs-44081/v1

License: (a) (i) This work is licensed under a Creative Commons Attribution 4.0 International License.

Read Full License 


\section{Abstract \\ Background}

Despite the existence of a preventive vaccine against hepatitis B viral (HBV) infection, approximately 250 million people are infected with the virus worldwide. Considering the burden of this infection, this study aimed at evaluating the level of knowledge, attitude and seropositivity of the disease among apparently healthy, potential blood donors at the blood service of the Bamenda Regional Hospital Blood Bank.

\section{Methods}

A cross sectional study was carried out from March to May 2019 among 250 blood donors. Following screening for Hepatitis B surface antigen (HBsAg) using the One step HBsAg test strip, information on the level of knowledge and attitude towards the infection was obtained using a self-administered questionnaire. Responses were graded as adequate knowledge or positive attitude if a cumulative score of $>50 \%$ was attained. Data was analyzed using the software IBM SPSS version 21.0. Multiple linear regression analysis was carried out to assess relationships between selected factors and knowledge of Hepatitis B. $p$-value of 0.05 was considered as statistical significance.

\section{Results}

The seropositivity of HBV was $6.4 \%$. Overall, $46.8 \%$ of the study participants had adequate knowledge while $76.3 \%$ had a positive attitude toward the disease. The highest seropositivity was observed in singles (7.1\%), primary school leavers (14.3\%), unskilled laborers (14.5\%) and replacement donors (9.33\%). The risk of being hepatitis B seropositive was higher in males as compared to females [OR: 3.1 $(95 \% \mathrm{Cl} 0.7-14)$. Participants with previous blood donation history were more protected [OR:0.4 (95\% Cl $0.1-1.2), p=0.130]$ compared to first time donors.

\section{Conclusion}

The prevalence of hepatitis B among blood donors in this blood service is in the high intermediate category. On the whole, the level of knowledge on this infection among these blood donors is average. These findings suggest that health education on HBV infection should be provided to the public as a major strategy to curb the infection.

\section{Background}

Hepatitis B caused by hepatitis B virus (HBV) is a major global health problem and potentially a lifethreatening liver infection. In 2015, an estimate of 257 million people were living with chronic hepatitis B 
infection and approximately, 887000 hepatitis-related deaths were recorded [1]. The prevalence of hepatitis $B$ infection varies geographically with the highest prevalence recorded in the Western Pacific and African Regions. The lifetime and mortality risks resulting from hepatitis B infection in sub-Saharan Africa and East Asia regions are estimated at about 60 and 25\% respectively [1,2]. Transmission is through contact with the blood or all other body fluids of an infected person. Although an effective vaccine for the virus has been available since 1982 [3] in preventing infection and the development of a chronic disease and liver cancer due to the disease, hepatitis B continues to be a serious public health problem. Many factors hinder vaccination against the infection amongst which is the cost, the required repeated doses and general community misconception [3].

Blood transfusion saves millions of lives yearly throughout the world. Due to the increasing number of accidents especially in the developing countries, and loss of blood owing to several pathologies including anemia, the demand of blood transfusion is on the rise. However, access to safe blood is a major problem mainly because of viral infections in blood notably, Human immunodeficiency virus (HIV), hepatitis B virus and hepatitis $C$ virus [4] in addition to blood shortage. Mbanya et al., [5] noted that only $80 \%$ of all donated blood is considered safe for distribution. Decades later, Virk and Hua reported a discard rate of $9 \%$ of blood in low-income countries due to the presence of infectious diseases in blood donations [6]. Among the transfusion transmissible infections (TTIS), HIV and HBV accounts for a higher proportion of discarded blood [5]. Even though the prevalence of HBV varies geographically, the rates remain high across most countries in Africa. While HBsAg seropositivity of $13.6 \%$ is reported in Nigeria, Cameroon records $11.2 \%[4,7]$. In a study carried out among students' voluntary blood donors in Egypt, the prevalence was $4.31 \%$, while $7.5 \%$ was reported in Ghana and $4.17 \%$ in Gabon [8-10]. These rates have significant impact on blood safety and hence underscores the necessity of proper use of donated blood.

The level of knowledge and attitude toward hepatitis B infection fluctuates between different groups of respondents. While those in the medical field demonstrate good knowledge, patients and others do not exhibit the same level of knowledge [11]. Among blood donors, general knowledge on the infection was $60 \%$ in a survey conducted at the Casablanca Regional Blood Transfusion Centre and $51.21 \%$ in North India with an attitude score of $47.93 \%[12,13]$. Several studies have been conducted in Cameroon and Africa on the prevalence of HBV among blood donors. There is, however, sparse information on the level of knowledge and attitude of donors towards HBV. Therefore, this study determined the seropositivity of HBsAg, evaluated general knowledge and attitude toward HBV infection among blood donors at the blood bank service of the Bamenda Regional Hospital, Cameroon.

\section{Methods}

\section{Study design and setting}

This was a cross sectional study carried out from March to May 2019. The study recruited all potential blood donors who came to donate blood at the Bamenda Regional Hospital Blood Service. This blood service is a major one in the region with an average of 3,500 blood donations received annually. The 
medical history (including transfusion history) and vital signs of each potential donor is noted, and the donor undergoes both clinical examination and laboratory screening for TTIs. Donor is rejected from blood donation if there is any underlying medical condition or any risk associated to donation. The admissible age group is 18 to 65 years with hemoglobin level $\geq 12.0 \mathrm{~g} / \mathrm{dl}$ (females) and $13.0 \mathrm{~g} / \mathrm{dl}$ (males). Female donors must not be pregnant, lactating or menstruating. Pre-donation counselling is done to assess the suitability of everyone against a set of selection criteria. The donor's responses to the questionnaire is reviewed during a confidential interview with a trained staff member. Opportunity is granted to the donor to enhance his/her understanding and compliance with the process of assessing donor suitability for blood donation and post-donation counselling procedures. Only donors who fulfilled these conditions and accepted to participate in the study by signing or thumb printing the informed consent form were recruited. All deferred donors were referred to the appropriate physician for further proper care management.

\section{Laboratory Analysis}

A venous blood sample was collected from each eligible donor and analyzed for HBsAg using the one step hepatitis B surface antigen test strip (Polymed Therapeutics Inc. Houston, USA). The test is based on the principle of chromatographic immunoassay for qualitative detection of the surface antigen of hepatitis B virus (HBsAg) in human whole blood, plasma, and serum samples. Testing and interpretation of test results was carried out using the manufacturer's instructions.

\section{Instrument and scoring criteria of knowledge and attitude}

Data on knowledge and attitude towards HBV infections was collected using a self-administered structured questionnaire. Where applicable, the questionnaire, which was originally in English was adapted and verbally administered in Pidgin English (broken English most widely spoken and understood language in the region) or French (one of the two official languages of the country). The questionnaire, which was divided into sections, generated information on the participant's sociodemographic characteristics, donor's level of knowledge and attitude towards the infection. In total, there were 33 questions on knowledge and each question was assigned a score of 1 for a total of 33 marks. A participant was deemed knowledgeable if the cumulative score was $>50 \%$. This flexible scoring system judged all with average knowledge as being knowledgeable. Scoring of attitudes was based on responses to seven questions encompassing the individual's perception on vulnerability to the infection, willingness to get tested and vaccinated and the mindset toward preventive strategies. Based on the responses, each correct response was attributed a mark for a total of 7 marks. In like manner, attitude was considered positive if a score of $>50 \%$ was attained by the respondent.

\section{Statistical analysis}

Data was analyzed using the statistical software IBM SPSS version 21.0 for windows. Continuous variables were checked for normality using Kolmogorov - Smirnov (K-S) test. Differences in mean knowledge score were compared across different factors using independent t-test and one-way ANOVA. 
Multiple linear regression analysis was carried out to assess relationships between selected factors and knowledge of Hepatitis $B$. We used logistic regression to determine associated risk factors to seropositivity. A two-tailed $p$-value of 0.05 was considered as statistical significance.

\section{Results}

\section{Seropositivity of HBsAg among the study participants}

During the study period, a total of 494 participants visited the blood bank. Of these, 244 were rejected. Reasons for rejection were previous blood donation less than 3 or 4 months for males and females respectively (57), elevated blood pressure (45), women under menstruation (37), younger than 18 years (6) and refusal to provide consent (99). Finally, 250 participants were retained for the study, with males, replacement donors and those of the age group 18-25 years dominating (Table 1). The prevalence of HBsAg among the blood donors was $6.4 \%$. As detailed in table 1, males, singles, those who had attained only primary level of education and the unskilled had the highest prevalence.

\section{Factors associated with seropositivity of HBsAg}

Bivariate analysis of the factors associated with seropositivity of HBsAg are shown in Table 2. Males, secondary level of education and unskilled profession were all associated with HBV infection although the correlation was not significant. On the other hand, donors who had attained university level of education and students were significantly associated with infection [OR: 4.1 (10.1 - 14.2), p=0.027 and OR: 11.9 (1.4 - 98.4), $p=0.021$ respectively]. Participants with previous blood donation history were more protected [OR:0.4 $(0.1-1.2), p=0.130$ ] compared to those that were donating blood for the first time. The difference was, however, not statistically significant (Table 2).

\section{Level of knowledge on HBV infection among the study participants}

Of the 250 participants, 117 (46.8\%) had adequate knowledge on HBV infection, mode of transmission and preventive measures. Females were more knowledgeable $(63.51 \%)$ than males $(39.77 \%)$ with the difference being statistically significant $(p<0.001)$. In like manner, significant differences were observed among age groups, level of education, occupation, and reason for blood

donation (Table 3). When the percent mean level of knowledge was assessed within each group, females, the age group of 18-25 years, those that had attained university education and students had a significantly higher level of knowledge compared to their counterparts within the group. On multiple regression analysis on the relationships between selected factors and knowledge, a significantly positive correlation was observed with the level of education and gender while participation in a health education program had a significantly negative relationship (Table 4).

\section{Attitude of participants towards HBV infection}


This study examined the attitude of these potential blood donors toward HBV infection. Overall, the participants had a mean positive attitude score of $76.3 \%$. As detailed in table 5 , slightly more than half (52.8\%) of the participants think that anyone can acquire the infection. While $89.6 \%$ are willing to do HBV test, there is a higher percentage $(90.8 \%)$ of those with a positive attitude to taking the vaccine if tested negative. Considering the availability of a vaccine at a cost of 9,000FCFA ( $\$ 15)$ only $75.6 \%$ of the participants had a positive attitude (Table 5).

\section{Discussion}

Transfusion transmissible infections such as HBV remains a significant threat to safe blood donation, especially in countries where the prevalence of these infections is high. For improved awareness and more efficient strategies to curb HBV infection to be employed, studies on the knowledge, attitude, and prevalence of the disease are necessary. This study evaluated the seropositivity, knowledge and attitude towards HBV infection amongst 250 blood donors at the Bamenda Regional Hospital Blood Service, which serves as a referral hospital for the entire North West Region of Cameroon.

In this study, the overall seropositivity of HBV infection was $6.4 \%$, with first time donors recording a seropositivity of $8.8 \%$. This "high intermediate category" observation on the overall seropositivity is lower than the reports of studies in other African countries including Ghana (7.5\% and $13.3 \%)$, Equatorial Guinea (10.01\%), Cameroon (12.6\%),Burkina Faso (14.47\%), and Togo (19.08\%) [9, 14-18]. Our findings are, nonetheless, higher than the recorded seroprevalence of $4.1 \%$ and 3.21 that was reported in respectively, Northwest Ethiopia and Madagascar (19-20). Among first-time donors, our prevalence was higher than the 7.28\% observed in Gabon (21) and lower than the 12.14\% in Yaoundé-Cameroon (22). Possible explanations for the relatively higher or lower seropositivity in this study include the differences in the epidemiology of HBV between different geographic regions, improvement in diagnostic technologies over the years with greater sensitivity and specificity, the economic status of the country and the increased sensitization about the disease.

Like Tagny et al., (23) and Nwobegahay et al., (24) who recorded $71.7 \%$ and $70.4 \%$ males respectively for blood donation, our study population also had $70.4 \%$ males. This could be explained by the fact that most females are rejected during donor examination because of physiological changes such as menstruation, pregnancy, and breastfeeding. The seropositivity was higher in males $(7.95 \%)$ than in females $(2.70 \%)$. The relatively higher seropositivity in males suggest other routes of exposure other than sex. This could be attributed to the use of unsterilized barbing razors to shave hair, outside socialization and multiple sex partners which is more common with males. Again, we observed that males were at a higher risk of being seropositive than females $(O R=3.1)$. Their behavioral activities could still account for this.

Those that had a history of previous blood donation were protected [ORs:0.4 (95\% Cl 0.1-1.2)] compared to first time donors. This is contrary to Jagannathan et al. who observed repeat donor status to be associated to HBsAg positivity (25). Our observation in this study could be explained by the fact that 
those who donate blood repeatedly are counselled on TTIs thus creating awareness on the diseases. Therefore, such donors may tend to adopt a more careful lifestyle compared to first time donors and this corroborates with the WHO recommendation for voluntary, regular, non-remunerated donors (26].

This study also revealed that $46.8 \%$ of our study population had adequate knowledge on hepatitis B infection. This result is slightly lower than those obtained by Boutayeb et al. and Bhasker et al. (12-13) who reported that $51.21 \%$ and $60 \%$ respectively of blood donors had good knowledge on Hepatitis B. Again, it is drastically lower than those seen in Nigeria (27) where $85 \%$ of the subjects had good knowledge on HBV. General knowledge on HBV infection in this community is still low. Although efforts on creating awareness about this infection is on the rise, the population is still less informed about it. We observed that participants in the age group 18-25 years were more knowledgeable as well as those who had attended higher education. This age category corresponds mainly to students. It further corroborates our observation on the positive relationship between a higher level of education and knowledge. The higher the student goes into education, the more he/she is exposed to various channels of information on the disease and a high level of understanding as well. Although we did not stratify the various disciplines of education, we realized that this group included students in the medical field. Such participants are expected to be more knowledgeable considering that hepatitis B is part of their teaching curriculum (28). When we considered the categories of donors, paid donors were more knowledgeable than voluntary, and the least was family/replacement donors. This could be explained by the fact that paid and voluntary donors probably donate blood regularly and are counselled on TTIs each time they come for donation. Family/replacement donors are seldom regular donors. Due to an emergency in most cases, such persons are sought to step in to provide blood for a relation. Some might be hearing about the infection for the first-time during a pre-donation counselling session. This scenario might justify the low level of knowledge among this group of participants. As expected, those who had never participated in any health education program related to hepatitis $B$ had a lower mean knowledge score compared to their counterpart that have taken part in one. This underscores the importance of more public education on the disease through various communication media and approaches to increase awareness.

When we evaluated attitude, the overall mean attitude score of $76.3 \%$ was obtained. This result was higher compared to that obtained by Bhasker et al (13) where only $47.1 \%$ of blood donors had a good attitude towards hepatitis B. Although the level of knowledge on HBV infection is slightly below average, the positive attitude of these participants toward the disease is an indication of their willingness to know and prevent the disease. Though $90.8 \%$ of the donors were willing to take the vaccine, only $75.6 \%$ were ready to pay for the vaccine at a cost of 9.000FCFA ( $\$ 15)$. Though not examined, we think that financial constraints account for the unwillingness to pay for such a vaccine. As a result, if cost is subsidized, more persons will be willing to take the vaccine for prevention.

Some limitations admitted in this study include the recruitment of participants restricted to the venue of blood donation, which may not be representative of the total blood donors' proportion of the region. Furthermore, the use of blood donors' population attending the Bamenda Regional Hospital Blood Bank may overestimate the level of knowledge and attitude towards the disease. That notwithstanding, this is 
the first study to the best of our knowledge to assess blood donors' seropositivity, knowledge, and attitude toward Hepatitis B in the North West Region of Cameroon. Since blood donation is a universal exercise that requires community participation; the results of our findings can be extrapolated to the situation in the community since these participants, coming from the community were recruited in an unbiased way.

\section{Conclusions}

Conclusively, the prevalence of HBV infection among blood donors at the blood bank service of the Bamenda Regional Hospital is $6.4 \%$. Males are at higher risk of being seropositive for HBsAg while those with a previous history of blood donation are at lower risk. Overall, the level of donors' knowledge on HBV infection was slightly below average (46.8\%) In total, $76.3 \%$ of the donors have a positive attitude towards the disease. We recommend that health education strategies about HBV infection be improved and adapted to provide control of transmission in the general public.

\section{Declarations}

\section{Acknowledgements}

The authors are grateful to all the study participants. We also express our gratitude to the management of the Blood bank for assistance during data collection.

\section{Authors' contribution}

MS conceived, designed, supervise the study, and prepared the manuscript, SS acquired data analyzed it, CTT and DM supervised the study and prepared the manuscript. All authors read and approved the final manuscript.

\section{Ethics declarations}

\section{Ethics approval and consent to participate}

Ethical clearance for the study was obtained from the Institutional Review Board of the University of Bamenda (2019/0033H/UBa/IRB) while administrative authorization was acquired from the Regional Delegation of Public Health for the North West Region (54/ATT/NWR/RDPH). Written informed consent was also obtained from all the study participants. The study was explained to all the participants and they were informed that participation was voluntary. Furthermore, they had the liberty to withdraw from the study at any time without any consequences on them. All the information obtained from the subjects were treated with utmost confidentiality.

\section{Competing interests}

None 


\section{Consent for publication}

Not applicable

\section{Funding}

There was no funding of the research.

\section{Availability of data and materials}

All data generated or analyzed during this study are included in the article. Data that support the findings of this study are also available from the corresponding author upon reasonable request.

\section{References}

1. World Health Organization. Hepatitis B: Fact Sheet. 2017. http://www.who.int/mediacentre/factsheets/fs204/en/index.html

2. Ofori-Asenso Richard, Agyeman Akosua Adom. Hepatitis B in Ghana: a systematic review \& metaanalysis of prevalence studies (1995-2015). BMC Infect Dis. 2016;16(1):130.

3. Musa BM, Busell S, Borodo MM, Samaila AA, Femi O. Prevalence of Hepatitis B virus infection in Nigeria, 2000 - 2013: A systematic review and meta-analysis. J. Clin. Pract. 2015;18(2):163-172

4. Negash, M., Ayalew, M., Geremew, D. et al.Seroprevalence and associated risk factors for HIV, Hepatitis B and C among blood Donors in South Gondar District blood Bank, Northwest Ethiopia. BMC Infect Dis. 19, https://doi.org/10.1186/s12879-019-4051-y

5. Mbanya D, Binam F, Kaptue L. Transfusion Outcome in a Resource-Limited of Cameroon: A Five-Year Evaluation. Int J Infect Dis. 2001; 5:70-73

6. Virk, Mrigender S and Hua Shan. "Approach to new microbial threats to blood safety." Annals of Botany4 (2019): 10-10.

7. Bigna JJ, Amougou MA, Asangbeh SL, Kenne AM, Nansseu JR. Seroprevalence of hepatitis C virus infection in Cameroon: A systematic review and meta-analysis. BMJ Open. 2017;7(8):1-11.

8. El-Gilany AH, El-Fedawy S. Bloodborne infections among student voluntary blood donors in Mansoura University, Egypt. East Mediterr1 Heal J. 2006;12(6):742-748.

9. Osei E, Lokpo SY, Agboli E. Sero-prevalence of hepatitis B infection among blood donors in a secondary care hospital, Ghana (2014): a retrospective analysis. BMC Res Notes. 2017;10(1):391.

10. Rérambhyia L, Gf N. Evaluation and Prevalence of Hepatitis B among Blood Donors in January June 2013 Gabon. 2015;2013-2015.

11. Sannathimmappa MB, Nambiar V, Arvindakshan R. Hepatitis B: Knowledge and awareness among preclinical year medical students. Avicenna J Med. 2019;9(2):43-47. doi:10.4103/ajm.AJM_164_18 
12. Boutayeb, H., Aamoum, A. \& Benchemsi, N. Knowledge about hepatitis $B$ and $C$ viruses and HIV among blood donors in Casablanca. EMHJ. 2006;12(5):538-547.

13. Bhasker B, Sachdev S, Marwaha N, Grover S, Singh T, Dhiman RK. Knowledge and Attitude Regarding Hepatitis B and C Among Blood Donors and Nondonors in North India. J Clin Exp Hepatol. 2019;9(3):318-323. doi:10.1016/j.jceh.2018.08.005

14. Xie DD, Li J, Chen JT, Eyi UM, Matesa RA, Obono MM, et al. Seroprevalence of Human Immunodeficiency Virus, Hepatitis B Virus, Hepatitis C Virus, and Treponema pallidum Infections among Blood Donors on Bioko Island, Equatorial Guinea. PloS one. 2015; 10(10):e0139947. https://doi.org/10.1371/ journal.pone.0139947 PMID: 26448460

15. Ankouane F, Noah Noah D, Atangana MM, Kamgaing Simo R, Guekam PR, Biwolé Sida M. Seroprevalence of hepatitis B and C viruses, HIV-1/2 and syphilis among blood donors in the Yaoundé Central Hospital in the centre region of Cameroon. Transfus Clin Biol. 2016;23(2):72-77. doi:10.1016/j.tracli.2015.11.008

16. Rufai T, Mutocheluh M, Kwarteng K, Dogbe $E$. The prevalence of hepatitis $B$ virus $E$ antigen among Ghanaian blood donors. The Pan Afr. med. 2014;17:53. https://doi.org/10.11604/pamj. 2014.17.53.3390 PMID: 25018803

17. Tao I, Compaoré TR, Diarra B, Djigma F, Zohoncon TM, Assih M, Ouermi D, Pietra V, Karou SD, Simpore J. Seroepidemiology of hepatitis B and C viruses in the general population of Burkina Faso. Hepat Res Treat. 2014;2014:781843. doi: 10.1155/2014/781843.

18. Kolou M, Katawa G, Salou M, Gozo-Akakpo KS, Dossim S, Kwarteng A, Prince-David M. High Prevalence of Hepatitis B Virus Infection in the Age Range of 20-39 Years Old Individuals in Lome. Open Virol J. 2017;12;11:1-7. doi: 10.2174/1874357901710011001. PMID: 28217218; PMCID: PMC5301296.

19. Tigabu, A., Engda, T. \& Mekonnen, F. Seroprevalence of transfusion transmissible viral infections (HIV, $\mathrm{HBV}$ and HCV) among voluntary blood donors at University of Gondar Comprehensive Specialized Hospital, Gondar; Northwest Ethiopia. BMC Infect Dis. 2019; 19:393. https://doi.org/10.1186/s12879019-3950-2

20. Arivelo RZ, Hendrison RD, Elie RF, Tantely RM, Ramamonjisoa A, Barnia RF, Paquerette HS, Raft HF, Aimée RA, Andry R. The seroprevalence of hepatitis B surface antigen among first time blood donors in Antananarivo (Madagascar) from 2003 to 2009. Blood Transfus. 2011;9(4):475-7. doi: 10.2450/2011.0102-10.

21. Eko Mba JM, Bisseye C, Ntsame Ndong JM, Mombo LE, Bengone C, Mouelet Migolet G, et al. Prevalent hepatitis B surface antigen among first-time blood donors in Gabon. PLoS ONE. 2018;13(4): e0194285. https://doi.org/10.1371/ journal.pone.0194285

22. Mbanya DN, Takam D, Ndumbet PM. Serologic findings among first time blood donors in Yaounde, Cameroon: Is safe donation a reality or a myth? Transfus Med. 2003;13(5):267-273

23. Tagny CT, Diarra A, Yahaya R, Hakizimana M, Nguessan A, Mbensa G, Nébié Y, Dahourou H, Mbanya D, Shiboski C, Murphy E, and Lefrère JJ. "Blood Donors and Blood Collection” Transfus. 2009; 
49:1592-9.

24. Nwobegahay JM, Njukeng PA, Kengne M, Ayangma CR, Abeng EM, Nkeza A, Tamoufe U, 2016. Prevalence of Hepatitis B virus infection among blood donors at the Yaounde Military Hospital, Cameroon. Microbiol Res Int. 2016;4(2): 6-10.

25. Jagannathan L, Chaturvedi M, Mudaliar S, Kumaladass T, Rice M, Murphy EL. Risk factors for chronic Hepatitis B virus infection among blood donors in Bangalore, India. Transfus Med. 2010; $20: 414-420$.

26. WHO, 2020. Blood Transfusion safety. https://www.who.int/bloodsafety/voluntary_donation/en/

27. Majolagbe O.N., Oladipo E.K., Daniel L.E. Prevalence and awareness of hepatitis B infection among blood donors in Abubakar Tafawa Balewa University Teaching Hospital (ATBUTH), Bauchi, Nigeria. Int J Multidiscip Curr Res. 2014; 2:955-960.

28. Ahmad, A., Munn Sann, L. \& Abdul Rahman, H. Factors associated with knowledge, attitude and practice related to hepatitis $\mathrm{B}$ and $\mathrm{C}$ among international students of Universiti Putra Malaysia. BMC Public Health 2016; 16:611 DOI 10.1186/s12889-016-3188-5

\section{Tables}

Table 1: Socio-demographic characteristics and seropositivity of HBsAg among 250 blood donors at the Blood Bank service 


\begin{tabular}{|c|c|c|c|c|}
\hline Variable & $\mathrm{N}(\%)$ & HBsAg +ve & HBsAg -ve & Seropositivity \\
\hline Overall & $250(100)$ & 16 & 234 & 6.40 \\
\hline \multicolumn{5}{|l|}{ Gender } \\
\hline Male & $176(70.4)$ & 14 & 162 & 7.95 \\
\hline Female & $74(29.6)$ & 2 & 72 & 2.70 \\
\hline \multicolumn{5}{|l|}{ Age group (years) } \\
\hline $18-25$ & $130(52.0)$ & 8 & 122 & 6.15 \\
\hline $26-33$ & $65(26.0)$ & 4 & 61 & 6.15 \\
\hline $34-57$ & $55(22.0)$ & 4 & 51 & 7.27 \\
\hline \multicolumn{5}{|l|}{ Marital status } \\
\hline Single & $183(73.2)$ & 13 & 170 & 7.1 \\
\hline Married & $65(26.0)$ & 3 & 62 & 4.6 \\
\hline Divorced/widowed & $2(0.8)$ & 0 & 2 & 0.0 \\
\hline \multicolumn{5}{|l|}{ Education } \\
\hline No formal education & $2(0.8)$ & 0 & 2 & 0.0 \\
\hline Primary & $35(14.0)$ & 5 & 30 & 14.3 \\
\hline Secondary & $60(24.0)$ & 5 & 55 & 8.3 \\
\hline Higher education & $153(61.2)$ & 6 & 147 & 3.9 \\
\hline \multicolumn{5}{|l|}{ Occupation } \\
\hline Student & $124(49.6)$ & 7 & 117 & 5.6 \\
\hline Unskilled & $55(22.0)$ & 8 & 47 & 14.5 \\
\hline Employed & $71(28.4)$ & 1 & 70 & 1.4 \\
\hline \multicolumn{5}{|l|}{ Residence } \\
\hline Rural & $46(18.4)$ & 2 & 44 & 4.3 \\
\hline Urban & $204(81.6)$ & 14 & 190 & 6.9 \\
\hline \multicolumn{5}{|l|}{ Religion } \\
\hline Christian & $224(89.6)$ & 13 & 211 & 5.8 \\
\hline Muslim & $19(7.6)$ & 2 & 17 & 10.5 \\
\hline Pentecostal & $7(2.8)$ & 1 & 6 & 14.3 \\
\hline \multicolumn{5}{|l|}{ History of blood donation } \\
\hline Yes & $125(50.0)$ & 5 & 120 & 4.0 \\
\hline No & $125(50.0)$ & 11 & 114 & 8.8 \\
\hline \multicolumn{5}{|l|}{ Reason for donating blood } \\
\hline Replacement & $150(60.0)$ & 14 & 136 & 9.33 \\
\hline Voluntary & $97(38.8)$ & 2 & 95 & 2.06 \\
\hline Paid & $3(1.2)$ & 0 & 3 & 0.00 \\
\hline
\end{tabular}

Table 2: Logistic regression observation on risk factors associated to HBsAg infection among blood donors $(\mathrm{N}=250)$ 


\begin{tabular}{|c|c|c|c|c|c|}
\hline \multicolumn{2}{|l|}{ arameters } & \multirow{2}{*}{$\begin{array}{l}\mathrm{N} \\
74 \\
\end{array}$} & \multirow{2}{*}{$\begin{array}{l}\text { Reactive (\%) } \\
2(2.7) \\
\end{array}$} & \multirow{2}{*}{$\begin{array}{l}\text { ORs 95\% CI } \\
\text { Ref }\end{array}$} & \multirow{2}{*}{$\begin{array}{l}p \text {-value } \\
0.140\end{array}$} \\
\hline znder: & Female & & & & \\
\hline & Male & 176 & $14(8.0)$ & $3.1(0.7-14.0)$ & \\
\hline \multirow[t]{3}{*}{ ye group: } & $18-25$ & 130 & $8(6.2)$ & Ref & \\
\hline & $26-33$ & 65 & $4(6.2)$ & $0.836(0.2-2.9)$ & 0.778 \\
\hline & $34-57$ & 55 & $4(7.3)$ & $0.836(0.2-3.5)$ & 0.807 \\
\hline \multirow[t]{3}{*}{ arital status: } & Single & 183 & $13(7.1)$ & Ref & \\
\hline & Married & 65 & $3(4.6)$ & Undefined & \\
\hline & Widow/widower & 2 & $0(0.0)$ & Undefined & \\
\hline \multirow[t]{4}{*}{ lucation: } & No formal education & 2 & $0(0.0)$ & Ref & \\
\hline & Primary & 35 & $5(14.3)$ & Undefined & \\
\hline & Secondary & 60 & $5(8.3)$ & $2.2(0.6-7.6)$ & 0.201 \\
\hline & Higher & 153 & $6(3.9)$ & $4.1(10.1-14.2)$ & 0.027 \\
\hline \multirow[t]{3}{*}{ scupation: } & Employed & 71 & $1(1.4)$ & Ref & \\
\hline & Unskilled & 55 & 8 (14.5) & $4.2(0.5-34.7)$ & 0.185 \\
\hline & Student & 124 & $7(5.6)$ & $11.9(1.4-98.4)$ & 0.021 \\
\hline \multirow[t]{2}{*}{ əsidence: } & Rural & 46 & $2(4.3)$ & Ref & \\
\hline & Urban & 204 & $14(6.9)$ & $0.6(0.1-2.8)$ & 0.533 \\
\hline \multirow[t]{3}{*}{ כligion: } & Christian & 224 & $13(5.8)$ & Ref & \\
\hline & Muslim & 19 & $2(10.5)$ & $0.4(0.04-3.3)$ & 0.373 \\
\hline & Pentecostal & 7 & $1(14.3)$ & $0.7(0.05-9.2)$ & 0.791 \\
\hline \multirow[t]{2}{*}{ evious blood donation: } & No & 125 & $11(8.8)$ & Ref & \\
\hline & Yes & 125 & $5(4.0)$ & $0.4(0.1-1.2)$ & 0.130 \\
\hline \multirow[t]{2}{*}{ you ask for a new sharp before use? } & Yes & 229 & $14(6.1)$ & Ref & \\
\hline & No & 21 & $2(9.5)$ & $0.6(0.1-2.9)$ & 0.545 \\
\hline
\end{tabular}

Table 3: Analysis of sociodemographic characteristics and blood donation history with level of knowledge $(\mathrm{N}=250)$ 


\begin{tabular}{|c|c|c|c|c|c|c|c|}
\hline \multicolumn{2}{|l|}{ Characteristics } & $\begin{array}{l}\text { Adequate } \\
\text { knowledge }\end{array}$ & $\begin{array}{l}\text { Inadequate } \\
\text { knowledge }\end{array}$ & $\begin{array}{l}p- \\
\text { value }\end{array}$ & $\begin{array}{l}\text { \%Mean } \\
\text { score }\end{array}$ & SD & $\begin{array}{l}p- \\
\text { value }\end{array}$ \\
\hline \multirow[t]{2}{*}{ Gender } & Male (176) & $70(37.8)$ & $106(60.2)$ & \multirow{2}{*}{$\begin{array}{l}< \\
0.001\end{array}$} & 38.0 & 28.4 & \multirow{2}{*}{0.001} \\
\hline & Female (74) & $47(63.5)$ & $27(36.5)$ & & 54.0 & 22.6 & \\
\hline \multirow[t]{3}{*}{ Age group (years) } & $18-25(130)$ & $76(58.5)$ & $54(41.5)$ & \multirow{3}{*}{0.001} & 48.5 & 27.6 & \multirow{3}{*}{0.003} \\
\hline & $26-33(65)$ & $22(33.8)$ & $43(66.2)$ & & 36.9 & 28.3 & \\
\hline & $34-57(55)$ & $19(34.5)$ & $36(65.5)$ & & 36.0 & 24.6 & \\
\hline \multirow[t]{3}{*}{ Marital status } & Single (183) & $95(52)$ & $88(48)$ & \multirow{3}{*}{0.025} & & & \\
\hline & Married (65) & $25(38.5)$ & $40(61.5)$ & & & & \\
\hline & $\begin{array}{l}\text { Widow / widower } \\
\text { (2) }\end{array}$ & $1(50)$ & $1(50)$ & & & & \\
\hline \multirow[t]{4}{*}{ Level of education } & $\begin{array}{l}\text { No formal } \\
\text { education (2) }\end{array}$ & $0(0)$ & $2(100)$ & \multirow{4}{*}{$\begin{array}{l}< \\
0.001\end{array}$} & 1.5 & 2.1 & \multirow{4}{*}{$\begin{array}{l}< \\
0.001\end{array}$} \\
\hline & Primary (35) & $11(31.4)$ & $24(68.6)$ & & 29.2 & 25.3 & \\
\hline & Secondary (60) & $12(20)$ & $48(80)$ & & 26.4 & 22.4 & \\
\hline & Higher (153) & $94(61.4)$ & $59(38.6)$ & & 52.8 & 25.5 & \\
\hline \multirow[t]{3}{*}{ Occupation } & Student (124) & $79(63.7)$ & $45(36.3)$ & \multirow{3}{*}{$\begin{array}{l}< \\
0.001\end{array}$} & 53.1 & 25.6 & \multirow{3}{*}{$\begin{array}{l}< \\
0.001\end{array}$} \\
\hline & Unskilled (55) & $14(25.5)$ & $41(74.5)$ & & 25.0 & 24.4 & \\
\hline & Employed (71) & $24(33.8)$ & $47(66.2)$ & & 38.4 & 25.9 & \\
\hline \multirow[t]{2}{*}{ Residence } & Rural (46) & $20(43.5)$ & $26(56.5)$ & \multirow{2}{*}{0.628} & 40.6 & 25.9 & \multirow{2}{*}{0.561} \\
\hline & Urban (204) & $97(47.5)$ & $107(52.5)$ & & 43.2 & 28.2 & \\
\hline \multirow[t]{3}{*}{ Religion } & Christians (224) & $107(47.8)$ & $117(52.2)$ & \multirow{3}{*}{0.542} & 43.8 & 27.4 & \multirow{3}{*}{0.161} \\
\hline & Muslims (19) & $8(42)$ & $11(58)$ & & 35.6 & 31.9 & \\
\hline & Pentecostal (7) & $2(28.6)$ & $5(71.4)$ & & 27.7 & 22.5 & \\
\hline \multirow[t]{2}{*}{ Previous blood donation } & Yes (125) & $61(48.8)$ & $64(51.2)$ & \multirow[b]{2}{*}{0.612} & 44.6 & 27.6 & \multirow[b]{2}{*}{0.278} \\
\hline & No (125) & $56(44.8)$ & $69(55.2)$ & & 40.8 & 27.8 & \\
\hline \multirow[t]{3}{*}{ Reason for donating blood } & $\begin{array}{l}\text { Replacement } \\
(150)\end{array}$ & $55(36.7)$ & $95(63.3)$ & \multirow{3}{*}{$\begin{array}{l}< \\
0.001\end{array}$} & 36.2 & 27.8 & \multirow{3}{*}{$\begin{array}{l}< \\
0.001\end{array}$} \\
\hline & Voluntary (97) & $59(60.8)$ & $38(39.2)$ & & 52.3 & 24.8 & \\
\hline & Paid (3) & $3(100)$ & $0(0)$ & & 64.7 & 18.4 & \\
\hline \multirow{2}{*}{$\begin{array}{l}\text { Participation in a health programme related } \\
\text { to Hepatitis B }\end{array}$} & Yes & 36 & 2 & \multirow{2}{*}{$\begin{array}{l}< \\
0.001\end{array}$} & 71.3 & 13.1 & \multirow{2}{*}{$\begin{array}{l}< \\
0.001\end{array}$} \\
\hline & No & 81 & 131 & & 37.8 & 26.4 & \\
\hline
\end{tabular}

SD: standard deviation

Table 4: Association between selected factors and knowledge on Hepatitis B 


\begin{tabular}{|l|l|l|l|}
\hline Factors & B & SE & $p$-value \\
\hline Constant & 66.4 & 14.7 & $<0.001$ \\
\hline Sex & 10.7 & 3.3 & 0.001 \\
\hline Age & 1.5 & 2.2 & 0.493 \\
\hline Education & 8.9 & 2.2 & $<0.001$ \\
\hline Occupation & -4.2 & 2.0 & 0.035 \\
\hline Residence & -1.2 & 3.7 & 0.741 \\
\hline Religion & -5.6 & 3.6 & 0.118 \\
\hline History of blood donation & -5.4 & 3.0 & 0.074 \\
\hline Reason for donating blood & 4.6 & 3.1 & 0.143 \\
\hline Health Education participation & -26.9 & 4.0 & $<0.001$ \\
\hline
\end{tabular}

B; regression coefficient, SE; standard error

Table 5: Attitude of the 250 potential blood donors towards hepatitis B

\begin{tabular}{|c|c|c|c|}
\hline Attitude & Responses & Frequency & Percentage \\
\hline \multirow[t]{3}{*}{ Do you think you can get hepatitis B? } & Yes & 132 & 52.8 \\
\hline & No & 69 & 27.6 \\
\hline & I do not know & 49 & 19.6 \\
\hline \multirow[t]{3}{*}{ Should everyone be tested for hepatitis B? } & Yes & 215 & 86.0 \\
\hline & No & 13 & 5.2 \\
\hline & I do not know & 22 & 8.8 \\
\hline \multirow[t]{3}{*}{ Will you like to take the test at any time? } & Yes & 224 & 89.6 \\
\hline & No & 11 & 4.4 \\
\hline & I do not know & 15 & 6.0 \\
\hline \multirow[t]{2}{*}{ If your test is negative, will you like to take the vaccine if available? } & Yes & 227 & 90.8 \\
\hline & No & 23 & 9.2 \\
\hline \multirow[t]{2}{*}{ If the vaccine is $9000 \mathrm{FCFA},(\sim \$ 15)$ will you pay for it in order to get vaccinated? } & Yes & 189 & 75.6 \\
\hline & No & 61 & 24.4 \\
\hline \multirow[t]{2}{*}{ Can you share household utensils with someone infected with hepatitis B? } & Yes & 119 & 47.6 \\
\hline & No & 131 & 52.4 \\
\hline \multirow[t]{2}{*}{ Will you ask for a new syringe or sharps before use? } & Yes & 229 & 91.6 \\
\hline & No & 21 & 8.4 \\
\hline
\end{tabular}

